\title{
The First Active Transcutaneous Bone Conduction Implant in Romania-Case Report of Permanent Conductive Hearing Loss Due to Cleft Palate
}

\author{
Madalina Georgescu ${ }^{1,2 *}$, Baumgartner $\mathrm{WD}^{3}$, Anca Modan ${ }^{2}$ and Daniela Vrinceanu ${ }^{4}$ \\ ${ }^{1}$ Institute of Phono Audiology and ENT Functional Surgery, Romania \\ ${ }^{2}$ Carol Davila University of Medicine and Pharmacy, Romania
}

${ }^{3}$ Ear, Nose and Throat Department, University Clinic Vienna, Austria

${ }^{4}$ ENT Department, Emergency University Hospital, Romania

*Corresponding author: Madalina Georgescu, ENT Consultant, Audiologist, Institute of Phono-Audiology and ENT Functional Surgery, University of Medicine and Pharmacy, Bucharest, Romania

submission: September 16, 2018; Published: October 03, 2018

\begin{abstract}
Since the introduction of bone conduction hearing implants in 1977, quality of life of the implantees have improved substantially. The first available option were bone-anchored hearing devices, which improved sound quality, but had the major disadvantage of post-operative skin and wound infections. Therefore, new technologies seeking intact skin solution have emerged lately. The BONEBRIDGE system (MED-EL, Medical Electronics, Innsbruck, Austria) incorporates the first active bone conduction device, which especially aims to resolve abutment issues and still offers excellent audiological benefit. The successful implantation of this system in the first Romanian patient suffering from congenital lip and hard palate cleft with recurrent suppurative otitis media is presented. The authors report their experience with implantation, in terms of indications, selection assessment as well as functional results with a critical review of advantages and disadvantages in comparison with classical methods.
\end{abstract}

\section{Introduction}

Hearing implants employing bone conduction (BC) stimulation have a long tradition (since 1977) and have become a standard care for patients suffering with conductive- or mixed hearing loss who cannot benefit from the conventional hearing aids. Since their development 40 years ago, there have been many improvements in both, the surgical approach, the technology itself and the way of fixation towards intact skin solutions of bone conduction hearing systems.

Existing percutaneous bone conduction implants (BCI) provide good audiological gain but are associated with a high rate of complications. 67 studies with a total of 6168 subjects were found reporting on safety outcomes of the percutaneous BAHA Connect bone conduction system since 2012 (date of first BONEBRIDGE implantation was used for literature search (Figure 1)). Despite good audiological rehabilitation results, the abutments of the BAHA percutaneous systems are at risk of complications (75.3\%), especially skin related issues like infection and skin overgrowth as high as $46,7 \%$ were found, as discussed elsewhere [1-67]. The Ponto system from Oticon Medicals slightly differs from the Baha Connect system, as it facilitates a longer abutment that does not require removal of the muscles and subcutaneous tissue. Both have similar audiological results, as discussed by Syms [68]. Safety issues in the Ponto System were reported in twelve studies in a total of 314 subjects, as discussed elsewhere [20,30,3,43,51,59,61-73]. Also, the Ponto system due to its percutaneous nature reports a high incidence rate of complications with $44.6 \%$ out of which the majority was related to skin complications (37.3\%). Thus, patients with the percutaneous kind of device need to have a commitment to life with the care of the skin where the device was placed, as discussed by Iseri [74].

In 2011 transcutaneous bone conduction implants, have become available: The Alpha Hearing System and the BAHA Attract, both conduct the sound through a titanium plate which is fixed under the skin through surgery, differing only in size and shape from each other. Despite the aesthetic and functional benefits, the devices cause skin friction generated by the powerful magnet, necessary to transfer the sound vibration to the skull efficiently, causing discomfort, vascularization difficulties and local skin irritation may lead to reduced wearing time [75]. Seventeen publications evaluating data of 210 subjects reported a $40.6 \%$ rate of safety outcomes for the Sophono Alpha 1 and Alpha 2, as discussed elsewhere [21,61,65,75-88]. The Baha Attract system reported 56.9\% safety outcomes in nine studies with a total of 153 subjects, as discussed elsewhere [47,75,83,89-94]. 
The BONEBRIDGE works differently from the Sophono Alpha Hearing System and BAHA Attract in that the Implant generates vibrational stimulation that is directly applied to the bone ("direct drive bone conduction stimulation"). Active transcutaneous bone conduction implants have the advantage over passive implants in that the vibrating part of the device is located under the skin, directly stimulating the bone through the screws, as discussed by Sprinzl [95]. Several studies have shown that BONEBRIDGE implantation offers an improvement of hearing thresholds and speech recognition, as discussed by Sprinzl [95] and fourteen studies showed a $7.4 \%$ rate of complications, as discussed elsewhere [49,88,96-107].

All above mentioned devices and indications were carefully considered before the here presented patient decided on the BONE-
BRIDGE device. In this report, we present the first BONEBRIDGE implantation performed in Bucharest, Romania. To the best of our knowledge, there have been no previous reports of this kind of implantation.

\section{Case Presentation}

A 25-years-old Caucasian male reported permanent hearing loss in the left ear. The patient's medical history included congenital lip and hard palate cleft with recurrent suppurative otitis media in the left ear. He underwent corrective procedures at the age of 3 for cleft closure and two surgeries in the left ear for otitis media, leaving him with a permanent conductive hearing loss.

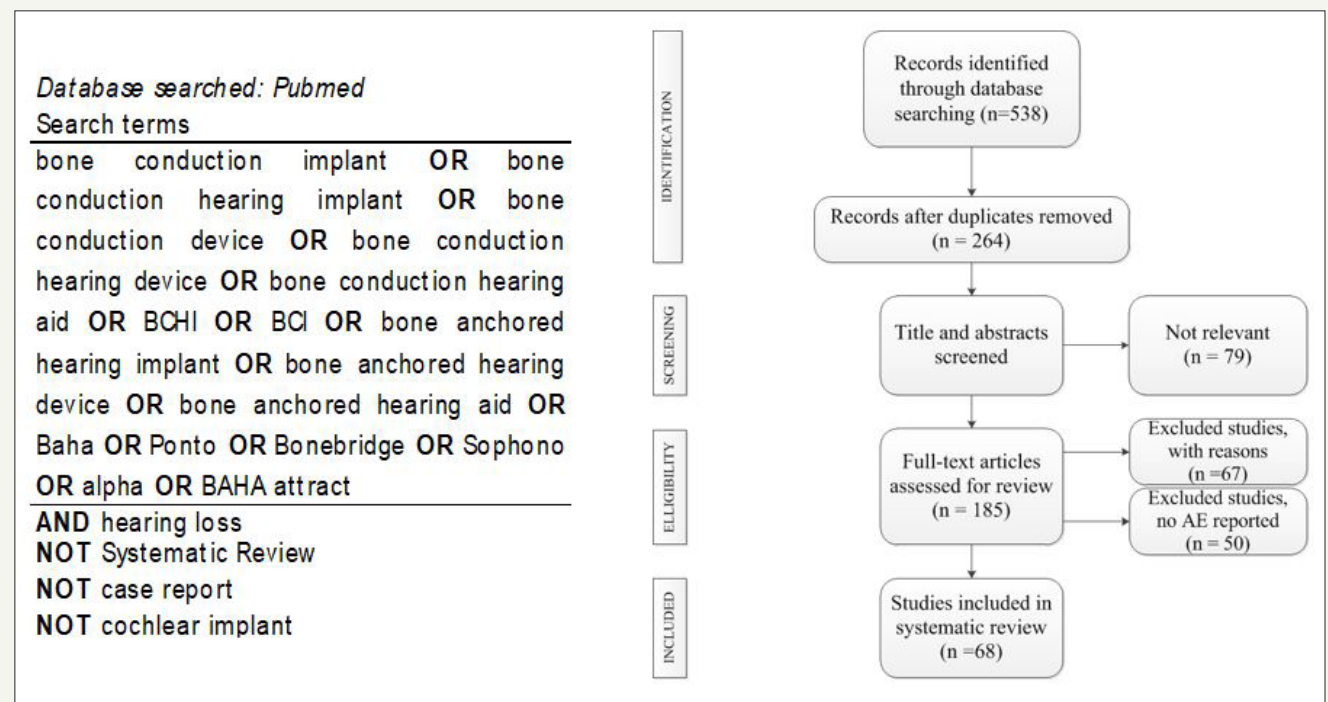

Figure 1: Search strategy used for searching PubMed databases (left) and flowchart of study selection (right).


Figure 2: Pure tone audiogram: Right ear - pre-op unaided mild conductive hearing loss (red); Left ear - pre-op moderate conductive hearing loss, post-op BB-aided condition; (BB-BONEBRIDGE); [ - BC masked, right ear;] - BC masked, left ear.

Examinations, otomicroscopy and audiological investigations revealed a mastoidian cavity widely communicating with the external auditory meatus in the left ear. The patient also presented a nasal septum deviation, with severe obstruction of the left na- sal pathway. Pure tone audiometry revealed moderate conductive hearing loss and a small perforation in the right eardrum with mild conductive hearing loss (Figure 2). 
Post-operative CT-scans in the left ear revealed $4 \mathrm{~mm}$ bone dehiscence of the lateral sinus and a dense deposit in the hypo-tympanum which was in contact with the facial aqueduct (Figure 3a \& 3b). The lamellar deposit in the mezzo-tympanum, attached to the promontory showed fibrous obstruction of the oval and round windows. No density anomalies in the compact bone of the inner ear were found, presenting normal permeability of the cochlea and semi-circular canals, without dehiscence. The absence of the ossicular chain led to moderate permanent conductive hearing loss.



Figure 3: High-resolution computed tomography temporal bone (a) axial section and (b) coronal section

(a) Right ear (axial view) chronic otomastoiditis sequelae $\left(^{*}\right)$ thick, retracted eardrum with perforation in the pars tensa); (\#) punctual erosion of the long incus arm (b) Left ear (coronal view): post-mastoidectomy status, $(\$)$ absence of the eardrum; (\$) dense lamellae in hypoand mezzo-tympanum, attached to the otic capsule, obstructing completely the oval (OW) and round windows (RW); complete absence of the ossicular chain (OC)
Luckily for the patient, despite the congenital cleft and nasal septum deviation, otitis media in the right ear was not so severe and the sequelae minor-with small eardrum perforation and mild conductive hearing loss. For this reason, language development of the patient was not affected, and he therefore only opted in adult age for a solution for his left ear hearing loss. No conventional hearing aid was recommended due to the mastoid cavity communicating widely with the external acoustic meatus. Recommended treatment included nasal surgery and a bone conduction hearing implant in the left ear. The candidate objected to the alternatives of a conventional percutaneous and passive transcutaneous BCI because of the stigmatization by the visible screw and the relatively high complication rates. Secondary reason to opt for BONEBRIDGE implantation was to avoid the need for life-long screw care [1-107].

Three months after nasal surgery, improved Eustachian tube function was measured via impedancemetry and the patient was scheduled for BONEBRIDGE implantation. Surgery was performed at the Phono-Audiology and Functional ENT Surgery Institute, Bucharest, Romania, under general anaesthesia. A presigmoid transmastoid approach was used to place the internal component in the drilled cavity, after removal of the chronic inflammatory mastoid mucosa. Due to a relative high position of the sigmoid sinus, elevators were used to ensure a proper position of the bone conduction implant (BCI). This was fixated with two Titanium screws in the normal density mastoid bone for best vibration transmission. The internal coil of the BONEBRIDGE was placed in a subperiostal pocket. Two layers closure of the muscular and skin layers was used, with different directions of the incisions.

No intra- nor postoperative complications occurred.

At four weeks after surgery, the Samba audio processor was switched on, and hearing evaluation was performed by pure tone and speech audiometry, immediately after activation and one week later. Results were similar at the two sessions: the PTA4 resulted in an improvement of 58.8dB (pre-op unaided 68.8; post-op best aided $10 \mathrm{~dB}$ ), with complete closure of the air-bone gap (ABG) on PTA and 100\%-word recognition score measured at $65 \mathrm{~dB}$ SPL using a Romanian language multisyllables-word test in quiet (post-op best-aided condition) (Figure 2 aided condition and Figure $4 \mathrm{~b}$ ).

\section{Discussion}

Recent literature suggests that implantation with the only active transcutaneous bone conduction hearing implant, is safe and effective for treating conductive and mixed hearing loss, as discussed by Sprinzl [95]. The surgical technique for insertion is easier than that of traditional surgeries, and there is no risk of inner ear damage. Due to the intact skin solution, with the internal part of the device being fully implanted without an abutment, the risk of skin infections is minimal. Furthermore, the active vibration 
without skin attenuation ensures more and better bone conduction gains than that of passive bone conduction devices [95]. The implantation of the BONEBRIDGE in this complex case due to its specific pathological condition of lip and hard palate cleft, inducing long-term dysfunction of the Eustachian tube and thus leading to recurrent suppurative otitis media episodes, presents good longterm solution with very satisfactory outcome. Postoperative audiological evaluation showed very good pure tone thresholds, with complete closure of the $\mathrm{ABG}$ and also excellent speech-recognition score at $65 \mathrm{~dB}$ SPL testing.

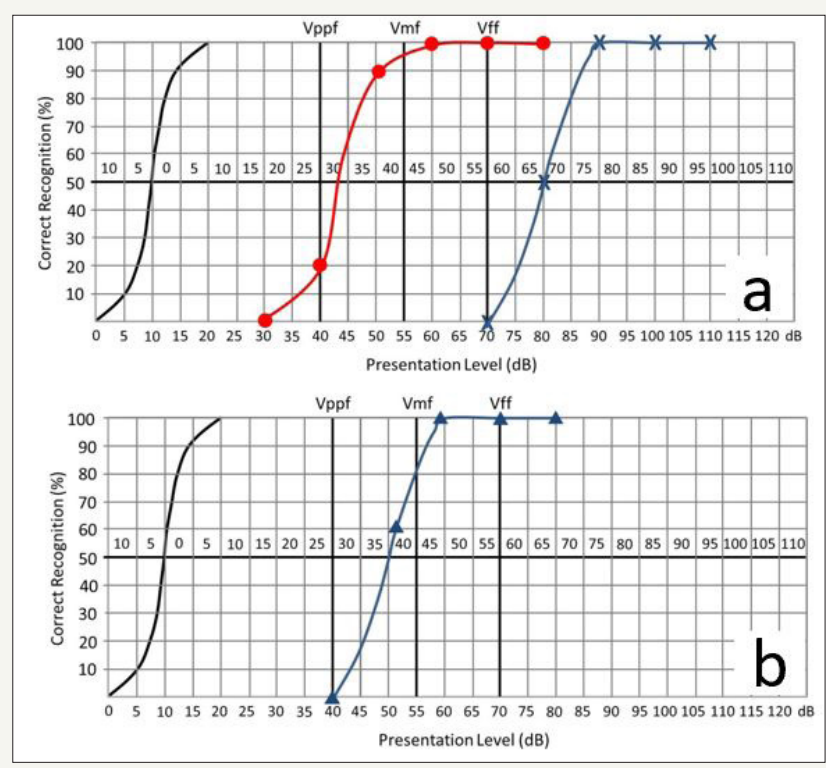

Figure 4: Word recognition score at 65dB after BONEBRIDGE implantation: (a) pre-op unaided (left and right ear (red) left ear (blue) (b) post-operative aided condition (left, operated ear); Vppf - vocal pianissimo (very soft loudness); Vmf - vocal mezzoforte (half-loud); Vff vocal fortissimo (very loud).

\section{Conclusion}

For the treatment of conductive hearing loss with complex underlying pathologies such as lip and hard palate cleft inducing chronic otitis media, BONEBRIDGE implantation is a promising option, offering a relatively easy surgical technique, very promising audiological outcomes, and high patient satisfaction.

\section{References}

1. Boleas A, Bulnes P, Erenchun LIR, Ibanez BB (2012) Audiological and subjective benefit results in bone-anchored hearing device users. Otol Neurotol 33(4): 494-503.

2. Bouhabel S, Arcand P, Saliba I (2012) Congenital aural atresia: Bone-anchored hearing aid vs. external auditory canal reconstruction. Int J Pediatr Otorhinolaryngol 76(2): 272-277.

3. D’Eredità R, Caroncini M, Saetti R (2012) The new Baha implant: A prospective osseointegration study. Otolaryngol Head Neck Surg 146(6): 979-983.

4. Dun CA, Faber HT, de Wolf MJ, Mylanus EA, Cremers CW, et al. (2012) Assessment of more than 1,000 implanted percutaneous bone conduction devices: Skin reactions and implant survival. Otol Neurotol 33(2): 192-198.

5. Horstink L, Faber HT, de Wolf MJ, Dun CA, Cremers CW, et al. (2012) Titanium fixtures for bone-conduction devices and the influence of type 2 diabetes mellitus. Otol Neurotol 33(6): 1013-1017.

6. Marsella P, Scorpecci A, D’Eredita R, Della Volpe A, Malerba P (2012) Stability of osseointegrated bone conduction systems in children: a pilot study. Otol Neurotol 33(5): 797-803.
7. McLarnon CM, Johnson I, Davison T, Hill J, Henderson B, et al. (2012) Evidence for early loading of osseointegrated implants for bone conduction at 4 weeks. Otol Neurotol 33(9): 1578-1582.

8. Rasmussen J, Olsen SØ, Nielsen LH (2012) Evaluation of long-term patient satisfaction and experience with the Baha ${ }^{\circledR}$ bone conduction implant. Int J Audiol 51(3):194-199.

9. Ray J, Addams WJ, Baldwin A (2012) Minimal access surgery for implantable bone conduction systems: Early experience with the "Sheffield" incision. Otol Neurotol 33(7): 1232-1234.

10. Saliba I, Froehlich P, Bouhabel S (2012) One-stage vs. two-stage BAHA implantation in a pediatric population. Int J Pediatr Otorhinolaryngol 76(12): 1814-1818.

11. Siau D, Nik H, Hobson JC, Roper AJ, Rothera MP, et al. (2012) Bone-anchored hearing aids and chronic pain: a long-term complication and a cause for elective implant removal. J Laryngol Otol 126(5): 445-449.

12. Tjellstrom A, Stalfors J (2012) Bone-anchored hearing device surgery: a 3-to-6-year follow-up with life table and worst-case scenario calculation. Otol Neurotol 33(5): 891-894.

13.Zeitler DM, Herman BS, Snapp HA, Telischi FF, Angeli SI (2012) Ethnic disparity in skin complications following bone-anchored hearing aid implantation. Ann Otol Rhinol Laryngol 121(8): 549-554.

14.Zeitler DM, Snapp HA, Telischi FF, Angeli SI (2012) Bone-anchored implantation for single-sided deafness in patients with less than profound hearing loss. Otolaryngol Head Neck Surg 147(1): 105-111.

15. Asma A, Ubaidah MA, Hasan SS, Wan FWH, Lim BY, et al. (2013) Surgical outcome of bone anchored hearing aid (baha) implant surgery: a 10years experience. Indian J Otolaryngol Head Neck Surg 65(3): 251254. 
16. Brant JA, Gudis D, Ruckenstein MJ (2013) Results of Baha® implantation using a small horizontal incision. Am J Otolaryngol 34(6): 641-645.

17. Darley MD, Mikulec AA (2013) Survival of the $8.5 \mathrm{~mm}$ osseointegrated abutment, and its utility in the obese patient. J Laryngol Otol 127(7): 643-649.

18. Doshi J, Banga R, Child A, Lawrence R, Reid A, et al. (2013) Quality-of-life outcomes after bone-anchored hearing device surgery in children with single-sided sensorineural deafness. Otol Neurotol 34(1):100-103.

19. Faber HT, Dun CA, Nelissen RC, Mylanus EA, Cremers CW, et al. (2013) Bone-anchored hearing implant loading at 3 weeks: Stability and tolerability after 6 months. Otol Neurotol 34(1): 104-110.

20. Goldman RA, Georgolios A, Shaia WT (2013) The punch method for bone-anchored hearing aid placement. Otolaryngol Head Neck Surg 148(5): 878-880.

21. Hol MK, Nelissen RC, Agterberg MJ, Cremers CW, Snik AF (2013) Comparison between a new implantable transcutaneous bone conductor and percutaneous bone-conduction hearing implant. Otol Neurotol 34(6): 1071-1075.

22. Lanis A, Hultcrantz M (2013) Percutaneous osseointegrated implant surgery without skin thinning in children: a retrospective case review. Otol Neurotol 34(4): 715-722.

23. Snapp H, Angeli S, Telischi FF, Fabry D (2013) Postoperative validation of bone-anchored implants in the single-sided deafness population. Otol Neurotol 34(4): 777-778.

24. Wilson DF, Kim HH (2013) A minimally invasive technique for the implantation of bone-anchored hearing devices. Otolaryngol Head Neck Surg 149(3): 473-477.

25. Allis TJ, Owen BD, Chen B, Jones DT, Moore GF (2014) Longer length Baha ${ }^{\mathrm{TM}}$ abutments decrease wound complications and revision surgery. Laryngoscope 124(4): 989-992.

26. Banga R, Reid AP, Proops DW, McDermott A, Stokes MA (2014) Perioperative considerations for children undergoing bone anchored hearing device surgery: an observational study. Eur Arch Otorhinolaryngol 271(6): 1437-1441.

27. Desmet J, Wouters K, Bodt DM, Vande H P (2014) Long-term subjective benefit with a bone conduction implant sound processor in 44 patients with single-sided deafness. Otol Neurotol 35(6): 1017-1025.

28. Fan Y, Zhang Y, Wang P, Wang Z, Zhu X, et al. (2014) The efficacy of unilateral bone-anchored hearing devices in Chinese Mandarin-speaking patients with bilateral aural atresia. JAMA Otolaryngol Head Neck Surg 140(4): 357-362

29. Farnoosh S, Mitsinikos FT, Maceri D, Don DM (2014) Bone-anchored hearing aid vs. reconstruction of the external auditory Canal in children and adolescents with congenital aural atresia: A comparison study of outcomes. Front Pediatr 2: 5

30. Federspil PA, Koch A, Schneider MH, Zaoui K (2014) Percutaneous titanium implants for bone conduction hearing aids: experience with 283 cases. HNO 62(7): 490-497.

31. Fontaine N, Hemar P, Schultz P, Charpiot A, Debry C (2014) BAHA implant: Implantation technique and complications. Eur Ann Otorhinolaryngol Head Neck Dis 131(1): 69-74.

32. Hultcrantz M, Lanis A (2014) Stability testing after osseointegrated implant surgery without skin thinning in children: case reports after abutment loss. Otol Neurotol 35(6): 1102-1104.

33. McLarnon C, Johnson I, Davison T, Hill J, Henderson B, et al. (2014) Resonance frequency analysis of osseo-integrated implants for bone conduction in a pediatric population-a novel approach for assessing stability for early loading. Int J Pediatr Otorhinolaryngol 78(4): 641-644.
34. Muzaffar SJ, Coulson CJ, Burrell S, Reid AP (2014) Initial experience of a rapid-insertion bone-anchored hearing system: series of 20 consecutive implants. J Laryngol Otol 23: 1-5.

35. Nelissen RC, Stalfors J, Wolf MJ, Flynn MC, Wigren S, et al. (2014) Longterm stability, survival, and tolerability of a novel osseointegrated implant for bone conduction hearing: 3-year data from a multicenter, randomized, controlled, clinical investigation. Otol Neurotol. 35(8): 1486-1491.

36. Pross SE, Layton A, Tong K, Lustig LR (2014) Cost of placement and complications associated with osseointegrated bone-conducting hearing prostheses: a retrospective analysis of medicare billing data. Otol Neurotol 35(3): 476-481.

37. Singam S, Williams R, Saxby C, Houlihan FP (2014) Percutaneous bone-anchored hearing implant surgery without soft-tissue reduction: up to 42 months of follow-up. Otol Neurotol 35(9): 1596-1600.

38. Wilkie MD, Chakravarthy KM, Mamais C, Temple RH (2014) Osseointegrated hearing implant surgery using a novel hydroxyapatite-coated concave abutment design. Otolaryngol Head Neck Surg 151(6): 10141019.

39. Amonoo-Kuofi K, Kelly A, Neeff M, Brown CR (2015) Experience of bone-anchored hearing aid implantation in children younger than 5 years of age. Int J Pediatr Otorhinolaryngol 79(4): 474-480.

40. Besten CA, Harterink E, McDermott AL, Hol MK (2015) Clinical results of cochlear BIA300 in children: Experience in two tertiary referral centers. Int J Pediatr Otorhinolaryngol 79(12): 2050-2055.

41. den Besten CA, Nelissen RC, Peer PG, Faber HT, Dun CA, et al. (2015) A retrospective cohort study on the influence of comorbidity on soft tissue reactions, revision surgery, and implant loss in bone-anchored hearing implants. Otol Neurotol 36(5): 812-818.

42. Faber HT, Nelissen RC, Kramer SE, Cremers CW, Snik AF, et al. (2015) Bone-anchored hearing implants in single-sided deafness patients: Long-term use and satisfaction by gender. Laryngoscope 125(12): 27902795 .

43. Gordon SA, Coelho DH (2015) Minimally invasive surgery for osseointegrated auditory implants: a comparison of linear versus punch techniques. Otolaryngol Head Neck Surg 152(6): 1089-1093.

44. Hildrew DM, Guittard JA, Carter JM, Molony TB (2015) Clobetasol's influence on the management and cost of skin overgrowth associated with the bone-anchored hearing aid. Ochsner J 15(3): 277-283.

45. Hogsbro M, Agger A, Johansen LV (2015) Successful loading of a bone-anchored hearing implant at two weeks after surgery: randomized trial of two surgical methods and detailed stability measurements. Otol Neurotol 36(2): e51-e57.

46. Hultcrantz M, Lanis A (2015) Prospective analysis of stability testing for bone-anchored hearing implants in children after osseointegrating surgery without skin thinning. Int J Pediatr Otorhinolaryngol 79(4): 465468

47. Iseri M, Orhan KS, Tuncer U, Kara A, Durgut M, et al. (2015) Transcutaneous bone-anchored hearing aids versus percutaneous ones: multicenter comparative clinical study. Otol Neurotol 36(5): 849-853.

48. Iseri M, Orhan KS, Yariktas MH, Kara A, Durgut M, et al. (2015) Surgical and audiological evaluation of the Baha BA400. J Laryngol Otol 129(1): 32-337.

49. Jovankovicova A, Stanik R, Kunzo S, Majakova L, Profant M (2015) Surgery or implantable hearing devices in children with congenital aural atresia: 25 years of our experience. Int J Pediatr Otorhinolaryngol 79(7): 975-979.

50. Larsson A, Tjellstrom A, Stalfors J (2015) Implant losses for the bone-anchored hearing devices are more frequent in some patients. Otol Neurotol 36(2): 336-340. 
51. McRackan TR, Goddard JC, Wilkinson EP, Slattery WH, Brackmann DE (2015) Bone-anchored hearing device placement with translabyrinthine tumor removal. Otolaryngol Head Neck Surg 152(2): 314-318.

52. Monini S, Musy I, Filippi C, Atturo F, Barbara M (2015) Bone conductive implants in single-sided deafness. Acta Otolaryngol 135(4): 381-388.

53. Nelissen RC, den Besten CA, Faber HT, Dun CA, Mylanus EA, et al. (2016) Loading of osseointegrated implants for bone conduction hearing at 3 weeks: 3-year stability, survival, and tolerability. Eur Arch Otorhinolaryngol 273(7): 1731-1737.

54. Nelissen RC, Mylanus EA, Cremers CW, Hol MK, Snik AF (2015) Longterm compliance and satisfaction with percutaneous bone conduction devices in patients with congenital unilateral conductive hearing loss. Otol Neurotol 36(5): 826-833.

55. Rebol J (2015) Soft tissue reactions in patients with bone anchored hearing aids. Ir J Med Sci 184(2): 487-491.

56. Wilkie MD, Lightbody KA, Salamat AA, Chakravarthy KM, Luff DA, et al. (2015) Stability and survival of bone-anchored hearing aid implant systems in post-irradiated patients. Eur Arch Otorhinolaryngol 272(6): 1371-1376.

57. Candreia C, Birrer R, Fistarol S, Kompis M, Caversaccio M, et al. (2016) Predisposing factors for adverse skin reactions with percutaneous bone anchored hearing devices implanted with skin reduction techniques. Eur Arch Otorhinolaryngol 273(12): 4185-4192.

58. Carr SD, Moraleda J, Baldwin A, Ray J (2016) Bone-conduction hearing aids in an elderly population: complications and quality of life assessment. Eur Arch Otorhinolaryngol 273(3): 567-571.

59. Dumon T, Medina M, Sperling NM (2016) Punch and Drill: implantation of bone anchored hearing device through a minimal skin punch incision versus implantation with dermatome and soft tissue reduction. Ann Otol Rhinol Laryngol 125(3): 199-206.

60. Kompis M, Wimmer W, Caversaccio M (2017) Long term benefit of bone anchored hearing systems in single sided deafness. Acta Otolaryngol 137(4):398-402.

61. Nelissen RC, Agterberg MJ, Hol MK, Snik AF (2016) Three-year experience with the Sophono in children with congenital conductive unilateral hearing loss: tolerability, audiometry, and sound localization compared to a bone-anchored hearing aid. European archives of oto-rhino-laryngology 273(10): 3149-3156.

62. Nelson KL, Cox MD, Richter GT, Dornhoffer JL (2016) A Comparative review of osseointegration failure between osseointegrated bone conduction device models in pediatric patients. Otol Neurotol 37(3): 276-280.

63. Roplekar R, Lim A, Hussain SS (2016) Has the use of the linear incision reduced skin complications in bone-anchored hearing aid implantation? J Laryngol Otol 130(6): 541-544.

64. Rosa F, Silva A, Reis C, Coutinho M, Oliveira J, et al. (2017) Bone Anchored Hearing Aid (BAHA) in children: Experience of a tertiary referral centre in Portugal. Acta Otorrinolaringol Esp 68(3): 151-156

65. Shin JW, Kim SH, Choi JY, Park HJ, Lee SC, et al. (2016) Surgical and audiologic comparison between sophono and bone-anchored hearing aids implantation. Clin Exp Otorhinolaryngol 9(1): 21-26.

66. Tompkins JJ, Petersen DK, Sharbel DD, McKinnon BJ, MacDonald CB (2016) Peri-implant bony overgrowth as a cause of revision surgery in auditory osseointegrated implantation. Int J Pediatr Otorhinolaryngol 86: 87-89.

67. Van der GK, Vanderveken O, Hamans E, Claes J, Van Rompaey V, et al. (2017) Adverse skin reactions following percutaneous bone conduction implant surgery using the linear incision technique with and without subcutaneous tissue reduction. Acta Otolaryngol 137(2): 149-153.

68. Syms MJ, Hernandez KE (2014) Bone conduction hearing: device auditory capability to aid in device selection. Otolaryngol Head Neck Surg

\section{0(5): 866-871}

69. den Besten CA, Bosman AJ, Nelissen RC, Mylanus EA, Hol MK (2016) Controlled clinical trial on bone-anchored hearing implants and a surgical technique with soft tissue preservation. Otol Neurotol 37(5): 504-512.

70. Foghsgaard S, Caye TP (2014) A new wide-diameter bone-anchored hearing implant-prospective 1-year data on complications, implant stability, and survival. Otol Neurotol 35(7): 1238-1241.

71. Mowinckel MS, Moller MN, Wielandt KN, Foghsgaard S (2016) Clinical outcome of a wide-diameter bone-anchored hearing implant and a surgical technique with tissue preservation. Otol Neurotol 37(4): 374-379.

72. Nelissen RC, Mylanus EA, Kunst HP, Pennings RJ, Snik AF, et al. (2013) A new bone-anchored hearing implant: short-term retrospective data on implant survival and subjective benefit. Eur Arch Otorhinolaryngol 270(12): 3019-3025

73. Wazen JJ, Babu S, Daugherty J, Metrailer A (2016) Three-week loading of the $4.5 \mathrm{~mm}$ wide titanium implant in bone anchored hearing systems. Am J Otolaryngol 37(2): 132-135.

74. Iseri M, Orhan KS, Kara A, Durgut M, Ozturk M, et al. (2014) A new transcutaneous bone anchored hearing device - the Baha(R) Attract System: the first experience in Turkey. Kulak Burun Bogaz Ihtis Derg 24(2): 5964.

75. da Silva VAR, Guimarães AC, Castilho AM, Crespo AN (2015) Bonebridge a new alternative of hearing rehabilitation for patients with single sided deafness or with conductive or mixed hearing loss. Austin Journal of Otolaryngology 2(3): 1032.

76. Baker S, Centric A, Chennupati SK (2015) Innovation in abutment-free bone-anchored hearing devices in children: Updated results and experience. International journal of pediatric otorhinolaryngology 79(10): $1667-1672$

77. Centric A, Chennupati SK (2014) Abutment-free bone-anchored hearing devices in children: initial results and experience. International journal of pediatric otorhinolaryngology 78(5): 875-878.

78. Denoyelle F, Coudert C, Thierry B, Parodi M, Mazzaschi O, et al. (2015) Hearing rehabilitation with the closed skin bone-anchored implant Sophono Alpha1: results of a prospective study in 15 children with ear atresia. International journal of pediatric otorhinolaryngology 79(3): 382-387.

79. Denoyelle F, Leboulanger N, Coudert C, Mazzaschi O, Loundon N, et al. (2013) New closed skin bone-anchored implant: preliminary results in 6 children with ear atresia. Otology \& neurotology 34(2): 275-281.

80. Leterme G, Bernardeschi D, Bensemman A, Coudert C, Portal JJ, et al. (2015) Contralateral routing of signal hearing aid versus transcutaneous bone conduction in single-sided deafness. Audiol Neurootol 20(4): 251-260.

81. Magliulo G, Turchetta R, Iannella G, Valperga di Masino R, de Vincentiis M (2015) sophono alpha system and subtotal petrosectomy with external auditory canal blind sac closure. European archives of oto-rhino-laryngol 272(9): 2183-2190.

82. Marsella P, Scorpecci A, Vallarino MV, Di Fiore S, Pacifico C (2014) Sophono in pediatric patients: the experience of an italian tertiary care center. Otolaryngol Head Neck Surg 151(2): 328-332.

83. O Niel MB, Runge CL, Friedland DR, Kerschner JE (2014) Patient outcomes in magnet-based implantable auditory assist devices. JAMA Otolaryngol Head Neck Surg 140(6): 513-520.

84. Powell HR, Rolfe AM, Birman CS (2015) A comparative study of audiologic outcomes for two transcutaneous bone-anchored hearing devices. Otology \& neurotology 36(9):1525-1531.

85. Siegert R (2010) Magnetic coupling of partially implantable bone conduction hearing aids without open implants. Laryngorhinootologie 89(6): 346-351. 
86. Siegert R (2011) Partially implantable bone conduction hearing aids without a percutaneous abutment (Otomag): technique and preliminary clinical results. Advances in oto-rhino-laryngology 71: 41-46.

87. Siegert R, Kanderske J (2013) A new semi-implantable transcutaneous bone conduction device: clinical, surgical, and audiologic outcomes in patients with congenital ear canal atresia. Otology \& neurotology 34(5): 927-934.

88. Sylvester DC, Gardner R, Reilly PG, Rankin K, Raine CH (2013) Audiologic and surgical outcomes of a novel, nonpercutaneous, bone conducting hearing implant. Otology \& neurotology 34(5): 922-926.

89. Zernotti ME, Di Gregorio MF, Galeazzi P, Tabernero P (2016) Comparative outcomes of active and passive hearing devices by transcutaneous bone conduction. Acta oto-laryngologica 136(6): 556-558.

90. Briggs R, Van Hasselt A, Luntz M, Goycoolea M, Wigren S, et al. (2015) Clinical performance of a new magnetic bone conduction hearing implant system: results from a prospective, multicenter, clinical investigation. Otol Neurotol 36(5): 834-841.

91. Carr SD, Moraleda J, Procter V, Wright K, Ray J (2015) Initial UK experience with a novel magnetic transcutaneous bone conduction device. Otol Neurotol 36(8):1399-1402.

92. Clamp PJ, Briggs RJ (2015) The Cochlear Baha 4 Attract System - design concepts, surgical technique and early clinical results. Expert Rev Med Devices 12(3): 223-230.

93. Gawecki W, Stieler OM, Balcerowiak A, Komar D, Gibasiewicz R, et al. (2016) Surgical, functional and audiological evaluation of new Baha Attract system implantations. Eur Arch Otorhinolaryngol 273(10): 31233130 .

94. Sharma S, Reddy Kolanu G, Marshall AH (2016) UK tertiary centre experience of outcomes from osseointegrated transcutaneous magnetic bone conduction hearing system implanted in twenty-five patients using a linear incision technique. Clin Otolaryngol 42(5):1041-1043.

95. Sprinzl GM, Wolf-Magele A (2016) The BONEBRIDGE bone conduction hearing implant: indication criteria, surgery and a systematic review of the literature. Clin Otolaryngol 41(2):131-43.

96. Baumgartner WD, Hamzavi JS, Boheim K, Wolf-Magele A, Schlogel M, et al. (2016) A new transcutaneous bone conduction hearing implant: short-term safety and efficacy in children. Otology \& neurotology 37(6):713-720

97. Eberhard KE, Olsen SO, Miyazaki H, Bille M, Caye-Thomasen P (2016)
Objective and subjective outcome of a new transcutaneous bone conduction hearing device: half-year follow-up of the first 12 nordic implantations. Otology \& neurotology 37(3): 267-275.

98. Ihler F, Volbers L, Blum J, Matthias C, Canis M (2014) Preliminary functional results and quality of life after implantation of a new bone conduction hearing device in patients with conductive and mixed hearing loss. Otology \& neurotology 35(2): 211-215.

99. Laske RD, Roosli C, Pfiffner F, Veraguth D, Huber AM (2015) Functional results and subjective benefit of a transcutaneous bone conduction device in patients with single-sided deafness. Otology \& neurotology 36(7):1151-1156.

100. Lassaletta L, Calvino M, Zernotti M, Gavilan J (2016) Postoperative pain in patients undergoing a transcutaneous active bone conduction implant (Bonebridge). European archives of oto-rhino-laryngology 273(12): 4103-4110.

101. Law EK, Bhatia KS, Tsang WS, Tong MC, Shi L (2016) CT pre-operative planning of a new semi-implantable bone conduction hearing device. Eur Radiol 26(6): 1686-1695.

102. Manrique M, Sanhueza I, Manrique R, de Abajo J (2014) A new bone conduction implant: surgical technique and results. Otology and Neurotology 35(2): 216-220.

103. Matsumoto N, Takumi Y, Cho B, Mori K, Usami S, et al. (2015) Template-guided implantation of the Bonebridge: clinical experience. European archives of oto-rhino-laryngology 272(12): 3669-3675.

104. Rahne T, Seiwerth I, Gotze G, Heider C, Radetzki F, et al. (2015) Functional results after Bonebridge implantation in adults and children with conductive and mixed hearing loss. European archives of oto-rhino-laryngology 272(11): 3263-3269.

105. Riss D, Arnoldner C, Baumgartner WD, Blineder M, Flak S, et al (2014) Indication criteria and outcomes with the Bonebridge transcutaneous bone-conduction implant. The Laryngoscope 124(12): 2802 2806.

106. Schmerber S, Deguine O, Marx M, Van de HP, Sterkers O, et al. (2017) Safety and effectiveness of the Bonebridge transcutaneous active direct-drive bone-conduction hearing implant at 1-year device use. European archives of oto-rhino-laryngology 274(4): 1835-1851.

107. Sprinzl G, Lenarz T, Ernst A, Hagen R, Wolf MA, et al. (2013) First European multicenter results with a new transcutaneous bone conduction hearing implant system: short-term safety and efficacy. Otology \& neurotology 34(6): 1076-1083.

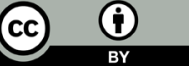

Creative Commons Attribution 4.0 International License

For possible submissions Click Here
Submit Article



\section{Trends in Telemedicine \& E-health}

\section{Benefits of Publishing with us}

- High-level peer review and editorial services

- Freely accessible online immediately upon publication

- Authors retain the copyright to their work

- Licensing it under a Creative Commons license

- Visibility through different online platforms 